G106

\title{
種々の製造等作業従事者のホルムアルデヒド懪露に係る 自覚症状調查
}

細井 香 1 、佐藤 敏彦 ${ }^{1} 、$ 工藤 安史 ${ }^{1}$ 、相澤 好治 ${ }^{1}$ 、山本 健也 ${ }^{2}$ 、高田 勗 ${ }^{2}$ ${ }^{1}$ 北里大学 医学部 衛生学公衆衛生学教室、 ${ }^{2}$ 中央労働災害防止協会・労働衛生調查分析センター

目的 新築・改築等による室内空気污染等により居住者にさまざまな体調不良が生じる症状を、総称して「シ ックハウス症候群」と呼んでいる。症状は、多様で、科学的には未だ未解明な部分が多い。要因としては、 建材等から発散する化学物質、暖房等の燃焼ガス、カビ・ダニ等のアレルゲン等による複合要因が影響して いると考えられている。厚生労働省（医薬局）はこれをうけ、シックハウス症候群の原因物質と考えられる ホルムアルデヒドなど 13 の化学物質に対し、室内濃度指針値を公表している。また、職域におけるホルム アルデヒド曝露防止については、厚生労働省 (労働基準局) からガイドラインが示されている。本研究では、 ホルムアルデヒド等に曝露または嚗露可能性のある瞕域における労働者の自覚症状の特徵を把握するため、 ホルムアルデヒド曝露者および非曝露者の自覚症状を比較し、ホルムアルデヒド曝露により特徴的な自覚症 状が存在するのかを調べるこを目的としている。対象と方法 ホルムアルデヒド曝露の可能性のある業種 と、ホルムアルデヒドを取り扱わない業種など 40 事業場の労働者 4,135 名のうち久損值等を除いた 3557 名 (男性 2944 名、女性 613 名) が解析人数である。質問票は、年路、性別、自覚症状として眼、鼻、のど、気 管、皮唐、筋肉・関節、消化器、自律神経、精神神経の症状の計 65 症状、過去の曝露状況、アレルギーの 有無、生活環境（職場、自宅、その他の空気曙境や改築の有無、空気による体調不良の有無など）、生活習慣 (睡眠時間、労働時間、ストレスの有無) の項目が含まれる。解析方法は、クロス表 $(2 \times 2$ 分割表) のセル の期待度数が 5 以下の場合には Fisher の直接法、それ以外には Pearson のカイ 2 乗検定(ノンパラメトリッ ク)を用いた。結果および考察 性別・曝露の有無別自覚症状有訴率を調べたところ、男性で、曝露の有無に より自覚症状有訴率間に有意差がみられた症状は全 65 症状中 26 症状、女性で、曝露の有無により自覚症状 有訴率間に有意差がみられた症状は全 65 症状中 10 症状であった。男性の曝露群で高頻度に訴えられた症状

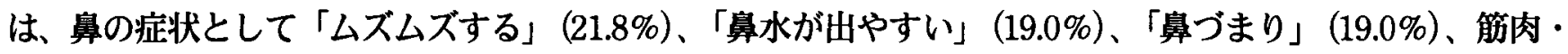

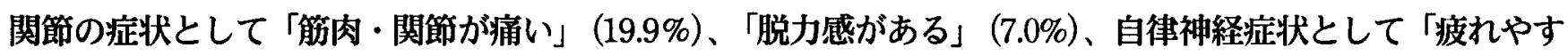
い $(18.0 \%) 、 「$ 体がだるい」 $(8.5 \%)$ 、咽頭症状として「かわく」(17.1\%)、精神神経症状として「いらいら する」(14.4\%) などがあげられた。曝露濃度を、非曝露群（非製造従事者）、曝露濃度 $0.08 \mathrm{ppm}$ 以下の低嚗 露群、曝露濃度 $0.08 \mathrm{ppm}$ を超える高曝露群に分けて調べたところ、高曝露群において訴えの多かった症状は、 鼻の症状、咽頭症状、皮膚の症状、自律神経症状、精神神経症状、気管支症状、消化器症状などであった。 特に、「皮庿のかゆい、「チクチクする、「あれる、「かわく、「咽頭がかわく、「痛い小、疲れやすい小、 「体がだるい、「めまい、たちくらみ、「物忘れが激しい、「将来に希望がもてない」などは、訴えの多い症 状であった。低曝露群において訴えの多かった症状は、「鼻がムズムズする小、筋肉・関節が痛い小「しび れ・ふるえがある」であった。低曝露群に比べ、高曝露群で訴えの多かったものは、皮虐の症状であった。 まとめ 本調查の結果から、ホルムアルデヒド嚗露により皮虚粘膜の刺激以外に自律神経症状、精神神経症 状が非嚗露群より高率にみられたが、調査対象者には他の化学物質への曝露もみられるため、その影響など についても検討する必要があると考えた。 